\title{
Strategic Management in the Family Businesses
}

\section{Learning Objectives}

After reading this chapter, you should be able to:

- Understand strategic management in the family businesses

- Know about the importance of governance in the family business

- Explain the family firms' internal organization in terms of resources, capabilities, and competitive advantages

- Learn about the risk taking in family firms

- Understand the family firm strategy implementation

\section{Profile: Sheetz}

Bob Sheetz founded Sheetz, Inc. in 1952 by purchasing one of his father's five dairy stores located in Altoona, Pennsylvania. In 1961, he hired his brother Steve Sheetz to work part-time at the store. The second store was opened under the name "Sheetz Kwik Shopper" in 1963. After opening the third store in 1968 , Steve joined Bob in the business as general manager in 1969. The brothers strategically planned to expand by opening one store per year with a target of seven stores by 1972. In 1972, the number of stores actually doubled by expanding from seven to 14 stores. One year later, Sheetz added gasoline pumps and introduced self-serve gasoline to Central Pennsylvania.

By 1983, Sheetz had opened 100 stores. The following year, Bob retired and handed over the leadership of the company to his brother Steve. In 1995, Stan Sheetz, Bob's son, became President, and Steve became Chair of the Board. With new family leadership, the company continued with growth and innovation such as touchscreen ordering feature for customers, Sheetz Bros. Coffeez, Made-To-Go, and Shweetz Bakery products by uniquely providing quality food at a convenience store context.

(continued) 
In 2013, the family leadership has been successfully transferred to Joe S. Sheetz (son of Bob's brother Joe M.) who became President and CEO. Stan became the Chair of the Board, and Steve took the role of Chair of the Sheetz Family Council. In 2015, Altoona, Pa.-based Sheetz was a leading regional chain of more than 500 convenience stores in Maryland, North Carolina, Ohio, Pennsylvania, Virginia, and West Virginia. At that stage, Joe Sheetz stated: "We are not for sale and will remain private." Joe Sheetz also explained that the family, in fact, did not own the entire company although multiple generations of Sheetz family were involved in the management team. Sheetz rather provides an Employee Stock Ownership Plan, and any employee with more than a year employment owns stock, as well as hundreds of former employees. Therefore, approximately most of 85 members of Sheetz family owned shares in the company along with 16,000 employees as of 2015. By 2017, Sheetz became the first two-time Chain of the Year winner in the award's 28-year history and was recognized by Fortune as one of the 100 Best Companies to Work For, a Top 12 Best Places to Work for Women, and Top 35 Best Workplaces for Millennials with nearly \$6 billion in revenue and approximately 18,000 employees.

Aside from an emphasis on employee care, Sheetz has also been a major supporter of charities. The company has been providing substantial amount of donations to charities along with two corporate charities, the Sheetz Family Charities and Special Olympics. The funds raised for Sheetz Family Charities go to the For the Kidz Holiday Event and the Make-A-Wish Foundation. Sheetz For the Kidz is a charitable organization operated by Sheetz employees. In 2016, it provided \$1.6 million to provide gifts to 9000 children for holidays. This has helped more than 100,000 children raising \$22.9 million. Through Make-A-Wish, Sheetz sponsors approximately 50 family trips to Walt Disney World annually. Since 2005, it has been able to grant more than 450 wishes. In 2017 , with also the help of customers, the company donated more than $\$ 650,000$ to the Special Olympics. Sheetz remains Pennsylvania's largest contributor to the organization and was an inductee into the Special Olympics Hall of Fame in 2000. As much as Sheetz family prioritizes education and personal development within the family, the company donates substantially to the education and developmental programs within the community such as the Boy and Girl Scouts, libraries, youth development, athletic, and arts programs.

In early 2020 , Sheetz was one of the fastest-growing family owned convenience store chains with more than 20,000 employees in the United States. The company operates 600 store locations throughout Pennsylvania, West Virginia, Virginia, Maryland, Ohio, and North Carolina. Moreover, the company has been recognized as one of the 2020 Fortune 100 Best Companies to Work For, according to global research and consulting firm Great Place to Work $^{\circledR}$ and Fortune magazine. This is the sixth time in 7 years that Sheetz has 
been included in this prestigious list. Sheetz CEO Joe Sheetz stated, "We are truly honored by this recognition and are deeply committed to investing in our people by providing competitive wages, substantial benefits, career growth opportunities and more to ensure they feel valued and have the resources they need to succeed." By this, Sheetz is an exemplary family business growing by not only focusing on the family but also its employees and community members by treating them as "family."

\title{
Sources
}

\author{
https://www.cspdailynews.com/technologyservices/measure-what-you- \\ treasure \\ https://www.cspdailynews.com/company-news/sheetz-says-forbes-got-it- \\ wrong \\ https://www.sheetz.com/us \\ https://cstoredecisions.com/2017/10/30/sheetz-earnz-2017-chain-year- \\ honors/ \\ https://www.wfmz.com/news/pr_newswire/pr_newswire_pennsylvania/great- \\ place-to-work-and-fortune-name-sheetz-one-of/article_b7b5ac16-0f5f- \\ 5f26-8b1d-3fa1ee2cd2e5.html
}

\subsection{Introduction}

In the preceding chapter, we covered that family's involvement in the business can lead to intentions to pursue unique goals and strategies, and controlling families are likely to exert a significant influence on firm behavior (Carney 2005; Memili et al. 2011). In other words, the "essence" of a family firm is thought to be a function of a family's influence on the culture, functioning, and behavior of the firm owing to the pursuit of a family's vision for the firm (Chrisman et al. 2003; Chrisman et al. 2005; Chua et al. 1999). Accordingly, a family firm's strategic behaviors tend to be oriented toward preserving the economic as well as non-economic value of the firm for the family in the long run (Gómez-Mejía et al. 2007; Le Breton-Miller and Miller 2006).

In this chapter, the profile family firm Sheetz exhibits growth as a primary strategy through employee care and empowerment, community engagement, and social responsibility. The fast growth of the convenience store chain is proficiently managed by the family as well as employee ownership. The strategies such as employee care, community engagement, and social responsibility are reflective of the family's strong commitment to values such as unity, harmony, and continuity not only within the family but also in the communities they serve in. 


\subsection{Importance of Governance in Family Firms}

Strategic management involves the analysis of internal and external environments of a firm in order to maximize the utilization of resources based upon firm objectives and goals (Bracker 1980). The attainment of competitive advantages and prosperity by that are crucial for all firms. Nevertheless, strategic management can be particularly important for family firms aiming the best use of the family's wealth and transgenerational prosperity.

The longer time horizon derived from an intention for continuing family control of the firm in order to preserve the family's continuity, stability, unity, and legacy can help its leaders avoid managerial myopia, forgo short-term earnings (Anderson and Reeb 2003; James 1999; Le Breton-Miller and Miller 2008; Upton et al. 2001), and direct efforts toward maintaining enduring relationships with key stakeholders such as employees, customers, and community members (Memili et al. 2011; Mustakallio et al. 2002; Zahra 2005), as can be seen in the profile firm Sheetz.

\subsection{Family Firm's Internal Organization}

\subsubsection{Resources and Capabilities}

Firm resources (i.e., tangible and intangible) such as assets, organizational processes, attributes, information, and knowledge are used to implement strategies (Barney 1991). Firms differ from each other in terms of resources and capabilities (Peteraf 1993). When these resources and capabilities are distinct and superior from those of the competitors, this can lead to competitive advantages (Peteraf 1993). The inability of competitors to duplicate the strategy makes a competitive advantage sustained (Barney 1991). Therefore, not all resources can lead to sustained competitive advantages. Only the firms with firm resources that are valuable, rare, inimitable, and non-substitutable can attain sustained competitive advantages (Barney 1991).

Within the context of family firms, the bundles of resources that are distinctive to each family firm, as a result of the family involvement and the interactions between the family, individual members, and the business, are identified as the "familiness" of the firm (Habbershon and Williams 1999). These bundles of resources involving unique human capital (i.e., knowledge, skills, and capabilities of employees), social capital (i.e., relationships between individuals or between organizations), patient capital (i.e., investment with a longer time horizon), and survivability capital (i.e., family members' contributions in the forms of free labor, loaned labor, equity investments, or financial loans) require strategic management in order to lead to competitive advantages (Sirmon and Hitt 2003). For instance, in the profile firm Sheetz, the firm invested in the development of both family and non-family employees that facilitated creativity and innovativeness, in turn leading to firm growth. 


\subsubsection{Competitive Position and Advantages}

While unique, rare, inimitable, and non-substitutable resources can lead to competitive advantages (Barney 1991), a firm can position itself relative to competitors along multiple dimensions including products, services, advertising and promotion, pricing, and distribution (Morrison and Roth 1992; Stewart and McAuley 2000). The extent to which a firm differentiates itself from competitors determines its competitive position (Knight 2000; White 1986; Wind and Robertson 1983).

Family firms' focus on the long haul is likely to lead to a competitive position and advantages through providing superior and sustainable value to stakeholders. For example, close monitoring and control by family owner managers with a long-term perspective can lead to a higher priority being given to the quality of products and services, which facilitates competitive positioning based on differentiation (Upton et al. 2001). The long-term orientation that occurs when the firm is viewed as a legacy to pass on to future generations also increases the value of developing strong relationships built on goodwill and trust with stakeholders (Poppo and Zenger 2002; Sako 1991; Weigelt and Camerer 1988). Indeed, the concern form the long haul may help family firms to leverage their patient investments and long-run strategies by demonstrating to stakeholders that they are here in the long run and committed to serving their long-term needs.

Furthermore, family owner managers that make business decisions based on a long-term commitment to both the family and the firm seem to develop stronger reputations with internal and external stakeholders based on the family name (Aronoff and Ward 1995; Dick and Basu 1994; Habbershon and Williams 1999; Lyman 1991). Since a competitive position seems more likely to lead to strong relationships and reputation with customers, family owner managers whose selfesteem and self-worth are tied to the family's continuing control of the business (Dutton et al. 1994; Smidts et al. 2001), may be more motivated to ensure that the firm develops such a competitive position and advantages via strategic management. Accordingly, family firms tend to avoid faddish trends (Craig et al. 2008) and hold a long-standing position through competitive positioning rather. Since the firm is considered as an entity to service the family's future generations through jobs, income, and security, intra-family succession intentions tend to push them to protect their family name and pursue competitive positioning for long-term prosperity and success (Dyer and Whetten 2006; Gómez-Mejía et al. 2007; Miller et al. 2007). Thus, family firms have strong incentives and motivation to develop a strong competitive position and advantages through strategic management. As we have seen in the Sheetz profile firm example at the beginning of this chapter, Sheetz family firm has been vigilant of the customers' changing needs, expectations, and lifestyles over time and adapted to those changes relatively quickly by constantly creating value to the customers and differentiating products and services from competitors. This ensured competitive position and advantages in its industry. 


\subsection{Risk Taking in Family Firms}

Risk taking in organizations involves considerations for financial risk due to commitment of assets and/or borrowing and the individual risk that firm leaders take in making such decisions while facing some chance of costly failure or high returns by capturing opportunities in the market (Brockhaus 1980; Lumpkin and Dess 1996; Lumpkin and Lichtenstein 2005; Miller and Friesen 1978).

In family firms, risk taking is pursued to ensure transgenerational sustainability and success (Corbetta and Salvato 2004; Zahra 2005). Indeed, research shows that entrepreneurial risk taking can lead to higher family firm performance (e.g., Memili et al. 2010). However, research shows that the level of risk taken in family firms tends to be lower than in non-family firms in both small- and medium-sized and publicly traded family firm contexts (Huybrechts et al. 2013; Naldi et al. 2007; Short et al. 2009). In the profile firm Sheetz, expansion involves a certain level of risk; however, it is closely monitored and controlled by family and employee owners, managers, board members, as well as the family council while remaining private.

\subsection{Family Firm Strategy Implementation}

Strategic decisions and implementation can be relatively easier and faster than in non-family firms in relatively small- and medium-sized family firms with unified ownership and management due to less bureaucracy (Welsch 1993). In larger and publicly traded family firms, family's involvement in corporate governance through ownership, management, and board also facilitates efficient decision-making in line with the controlling family's preferences in many cases (Memili 2011). In publicly traded family firm context, family owners participate in governance by voting based upon equity rights. Top management team often involving family members makes strategic decisions, and the board also involving family members approves (or disapproves). Once a strategic decision is approved, then strategic implementation takes place.

\subsection{Summary}

This chapter takes a closer look at strategic management in the family businesses as it is important in family firms' long-term survival and success. Resources and capabilities and strategic decisions on the effective use of them can lead to competitive advantages in the market's family firms are operating. Strategic decisions and actions also involve certain levels of risk taking. The controlling families tend to be influential on decisions and implementation depending on the level of their involvement in governance through ownership, management, and/or board membership. 


\section{Case Study: Walmart Inc.}

Sam Walton started his family business as a single discount store with the idea of selling more for less in Rogers, Arkansas, in 1962 and eventually became the largest global retailer in the world. There are currently 11,500 Walmart stores in 27 countries and ecommerce websites with revenue of $\$ 524$ billion and 2.2 million associates across countries in 2020 .

The company officially incorporated as Wal-Mart Stores, Inc. in 1969, became publicly traded in 1970, and was listed on the New York Stock Exchange in 1972. This facilitated further expansion of the business. The company added Sam's Club to its stores chain in Midwest City, Oklahoma, in 1983. In the 1990s, Walmart started going global by opening and/or acquiring stores in Mexico, Canada, China, and the United Kingdom.

In 1988, Sam Walton's CEO position was transferred to a non-family executive David Glass while Walton remained as Chair of the Board. David Glass had been in the company with various prominent roles such as Executive Vice President of Finance for Wal-Mart Stores, Vice Chairman, Chief Finan cial Officer, and Chief Operating Officer since 1976 until January 2000. Glass was also a member of the board of Wal-Mart Stores, Inc. from 1976 until his death in 2020 .

In 2000, H. Lee Scott, Jr. became the CEO. Walmart.com was founded, and US customers started shopping Walmart products and services online. This and continuing store expansion led to Walmart's Fortune 500 ranking of America's largest companies for the first time in 2002. In 2009, Mike Duke became the CEO. Then, Doug McMillon succeeded Mike Duke as CEO in 2014 as the company continued to grow. In 2015, Rob Walton, the eldest son of Helen and Sam Walton, retired as the Chair of the Board after his tenure in this role for 23 years, and he continues to serve as a director. Greg Penner succeeded Rob Walton as the Chair of Wal-Mart Stores, Inc.

In 2018, the company changed its legal name from Wal-Mart Stores, Inc. to Walmart Inc., and Judith McKenna became President and CEO of Walmart International. In 2019, John Furner was appointed to be the President and CEO of Walmart in the United States. In the early 2020, while Walton family was represented by the board members Rob Walton and Steuart Walton and family shareholders, the majority of the executive managers and the board members were professionals who were non-family members.

Although the founder Sam Walton had passed away shortly after receiving the Presidential Medal of Freedom in 1992, his 10 Rules for Building a Business that are shared in the corporate web site have been the guiding light for company leadership to date: 
1. Commit to your business.

2. Share your profits with all your associates and treat them as partners.

3. Motivate your partners.

4. Communicate everything you possibly can to your partners.

5. Appreciate everything your associates do for the business.

6. Celebrate your success.

7. Listen to everyone in your company.

8. Exceed your customers' expectations.

9. Control your expenses better than your competition.

10. Swim upstream.

\section{Questions}

1. Aside from the successful global expansion and innovations such as online selling, could there be other strategies you may recommend to the Walmart Inc. leadership?

2. What could be some issues and challenges Walmart Inc. may face during Covid-19 outbreak? How can they be solved?

3. What strategic changes would you recommend to Walmart Inc. in the short run and in the long run?

\section{Sources}

https://corporate.walmart.com/our-story

https://corporate.walmart.com/our-story/our-history

https://corporate.walmart.com/our-story/our-business

https://corporate.walmart.com/our-story/leadership

\section{Questions for Discussion}

- How do family business members participate in strategic management?

- Why is strategic management important in the family business?

- Explain family firms' internal organization

- What are the differences between family and non-family firms in terms of risk taking?

- Explain strategy implementation in family firms

\section{Additional Readings}

- Arregle, J. L., Hitt, M. A., Sirmon, D. G., \& Very, P. (2007). The development of organizational social capital: Attributes of family firms. Journal of management studies, 44(1), 73-95.

- Chrisman, J. J., Chua, J. H., \& Litz, R. (2003). A unified systems perspective of family firm performance: An extension and integration. Journal of Business Venturing, 18(4), 467-472. 
- Chrisman, J. J., Chua, J. H., \& Zahra, S. A. (2003). Creating wealth in family firms through managing resources: Comments and extensions. Entrepreneurship Theory and Practice, 27(4), 359-365.

- Danes, S. M., Stafford, K., Haynes, G., \& Amarapurkar, S. S. (2009). Family capital of family firms: Bridging human, social, and financial capital. Family Business Review, 22(3), 199-215.

- Eddleston, K. A., Kellermanns, F. W., \& Sarathy, R. (2008). Resource configuration in family firms: Linking resources, strategic planning and technological opportunities to performance. Journal of Management Studies, 45(1), 26-50.

- Zahra, S. A. (2005). Entrepreneurial risk taking in family firms. Family business review, 18(1), 23-40.

- Zahra, S. A. (2010). Harvesting family firms' organizational social capital: A relational perspective. Journal of Management Studies, 47(2), 345-366.

- Zahra, S. A., Hayton, J. C., \& Salvato, C. (2004). Entrepreneurship in family vs. non-family firms: A resource-based analysis of the effect of organizational culture. Entrepreneurship theory and Practice, 28(4), 363-381.

- Zellweger, T., \& Sieger, P. (2012). Entrepreneurial orientation in long-lived family firms. Small Business Economics, 38(1), 67-84.

\section{Suggested Activities}

- Select one family business and one non-family firm. Compare them in terms of risk taking.

- Find a family business implementing a strategy such as growth through expansion. Analyze the resources, capabilities, competitive position, and competitive advantages of this family firm.

\section{Keywords}

- Strategic management

- Resources

- Competitive position

- Risk taking

- Internal organization

- Competitive advantages

- Strategy implementation

- Familiness

- Human capital

- Social capital

- Patient capital

- Survivability capital 


\section{References}

Anderson, R. C., \& Reeb, D. M. (2003). Founding-family ownership, corporate diversification, and firm leverage. The Journal of Law and Economics, 46(2), 653-684.

Aronoff, C. E., \& Ward, J. L. (1995). Family-owned businesses: A thing of the past or a model for the future? Family Business Review, 8(2), 121-130.

Barney, J. (1991). Firm resources and sustained competitive advantage. Journal of Management, 17 (1), 99-120.

Bracker, J. (1980). The historical development of the strategic management concept. Academy of Management Review, 5(2), 219-224.

Brockhaus, R. H., Sr. (1980). Risk taking propensity of entrepreneurs. Academy of Management Journal, 23(3), 509-520.

Carney, M. (2005). Corporate governance and competitive advantage in family-controlled firms. Entrepreneurship Theory and Practice, 29(3), 249-265.

Chrisman, J. J., Chua, J. H., \& Litz, R. (2003). A unified systems perspective of family firm performance: An extension and integration. Journal of Business Venturing, 18(4), 467-472.

Chrisman, J. J., Chua, J. H., \& Sharma, P. (2005). Trends and directions in the development of a strategic management theory of the family firm. Entrepreneurship Theory and Practice, 29(5), $555-575$.

Chua, J. H., Chrisman, J. J., \& Sharma, P. (1999). Defining the family business by behavior. Entrepreneurship Theory and Practice, 23(4), 19-39.

Corbetta, G., \& Salvato, C. (2004). Self-serving or self-actualizing? Models of man and agency costs in different types of family firms: A commentary on "Comparing the agency costs of family and non-Family firms: Conceptual issues and exploratory evidence". Entrepreneurship Theory and Practice, 28(4), 355-362.

Craig, J. B., Dibrell, C., \& Davis, P. S. (2008). Leveraging family-based brand identity to enhance firm competitiveness and performance in family businesses. Journal of Small Business Management, 46(3), 351-371.

Dick, A. S., \& Basu, K. (1994). Customer loyalty: Toward an integrated conceptual framework. Journal of the Academy of Marketing Science, 22(2), 99-113.

Dutton, J. E., Dukerich, J. M., \& Harquail, C. V. (1994). Organizational images and member identification. Administrative Science Quarterly, 239-263.

Dyer, W. G., Jr., \& Whetten, D. A. (2006). Family firms and social responsibility: Preliminary evidence from the S\&P 500. Entrepreneurship Theory and Practice, 30(6), 785-802.

Gómez-Mejía, L. R., Haynes, K. T., Núñez-Nickel, M., Jacobson, K. J., \& Moyano-Fuentes, J. (2007). Socioemotional wealth and business risks in family-controlled firms: Evidence from Spanish olive oil mills. Administrative Science Quarterly, 52(1), 106-137.

Habbershon, T. G., \& Williams, M. L. (1999). A resource-based framework for assessing the strategic advantages of family firms. Family Business Review, 12(1), 1-25.

Huybrechts, J., Voordeckers, W., \& Lybaert, N. (2013). Entrepreneurial risk taking of private family firms: The influence of a nonfamily CEO and the moderating effect of CEO tenure. Family Business Review, 26(2), 161-179.

James, H. S. (1999). Owner as manager, extended horizons and the family firm. International Journal of the Economics of Business, 6(1), 41-55.

Knight, G. (2000). Entrepreneurship and marketing strategy: The SME under globalization. Journal of International Marketing, 8(2), 12-32.

Le Breton-Miller, I., \& Miller, D. (2006). Why do some family businesses out-compete? Governance, long-term orientations, and sustainable capability. Entrepreneurship Theory and Practice, 30(6), 731-746.

Le Breton-Miller, I., \& Miller, D. (2008). To grow or to harvest? Governance, strategy and performance in family and lone founder firms. Journal of Strategy and Management, 1 (1):41-56. 
Lumpkin, G. T., \& Dess, G. G. (1996). Clarifying the entrepreneurial orientation construct and linking it to performance. Academy of Management Review, 21(1), 135-172.

Lumpkin, G. T., \& Lichtenstein, B. B. (2005). The role of organizational learning in the opportunity-recognition process. Entrepreneurship Theory and Practice, 29(4), 451-472.

Lyman, A. R. (1991). Customer service: Does family ownership make a difference? Family Business Review, 4(3), 303-324.

Memili, E. (2011). Control-enhancing corporate governance mechanisms: Family versus nonfamily publicly traded firms. Mississippi State University.

Memili, E., Eddleston, K. A., Kellermanns, F. W., Zellweger, T. M., \& Barnett, T. (2010). The critical path to family firm success through entrepreneurial risk taking and image. Journal of Family Business Strategy, 1(4), 200-209.

Memili, E., Chrisman, J., Chua, J., Chang, E., \& Kellermanns, F. (2011). The determinants of family firms' subcontracting: A transaction cost perspective. Journal of Family Business Strategy, 2(1), 26-33. https://doi.org/10.1016/j.jfbs.2011.01.003.

Miller, D., \& Friesen, P. H. (1978). Archetypes of strategy formulation. Management Science, 24 (9), 921-933.

Miller, D., Le Breton-Miller, I., Lester, R. H., \& Cannella, A. A., Jr. (2007). Are family firms really superior performers? Journal of Corporate Finance, 13(5), 829-858.

Morrison, A. J., \& Roth, K. (1992). A taxonomy of business-level strategies in global industries. Strategic Management Journal, 13(6), 399-417.

Mustakallio, M., Autio, E., \& Zahra, S. (2002). Relational and contractual governance in family firms: Effects on strategic decision making. Family Business Review, 15(3), 205-222.

Naldi, L., Nordqvist, M., Sjöberg, K., \& Wiklund, J. (2007). Entrepreneurial orientation, risk taking, and performance in family firms. Family Business Review, 20(1), 33-47.

Peteraf, M. A. (1993). The cornerstones of competitive advantage: A resource-based view. Strategic Management Journal, 14(3), 179-191.

Poppo, L., \& Zenger, T. (2002). Do formal contracts and relational governance function as substitutes or complements? Strategic Management Journal, 23(8), 707-725.

Sako, M. (1991). The role of trust in Japanese buyer-supplier relationships. Ricerche economiche, 45, 449-473.

Short, J., Payne, G., Brigham, K., Lumpkin, G., \& Broberg, J. (2009). Family firms and entrepreneurial orientation in publicly traded firms. Family Business Review, 22(1), 9-24.

Sirmon, D. G., \& Hitt, M. A. (2003). Managing resources: Linking unique resources, management, and wealth creation in family firms. Entrepreneurship Theory and Practice, 27(4), 339-358.

Smidts, A., Pruyn, A. T. H., \& Van Riel, C. B. (2001). The impact of employee communication and perceived external prestige on organizational identification. Academy of Management Journal, 44(5), 1051-1062.

Stewart, D. B., \& McAuley, A. (2000). Congruence of domestic and export marketing strategies-An empirical investigation of its performance implications. International Marketing Review, 17(6), 563-586.

Upton, N., Teal, E. J., \& Felan, J. T. (2001). Strategic and business planning practices of fast growth family firms. Journal of Small Business Management, 39(1), 60-72.

Weigelt, K., \& Camerer, C. (1988). Reputation and corporate strategy: A review of recent theory and applications. Strategic Management Journal, 9(5), 443-454.

Welsch, J. H. (1993). The impact of family ownership and involvement on the process of management succession. Family Business Review, 6(1), 31-54.

White, R. E. (1986). Generic business strategies, organizational context and performance: An empirical investigation. Strategic Management Journal, 7(3), 217-231.

Wind, Y., \& Robertson, T. S. (1983). Marketing strategy: New directions for theory and research. Journal of Marketing, 47(2), 12-25.

Zahra, S. A. (2005). Entrepreneurial risk taking in family firms. Family Business Review, 18(1), $23-40$. 